\section{approach}

\section{Paris}

Just two weeks after the official start of the massive US programme to sequence the human genome, France has decided to boost its own research efforts with the aim of garnering efficiently many of the fruits of research on the human genome. "We will eat the chocolate without the bread", is how Philippe Kourilsky of the Pasteur Institute describes the decision to concentrate on the 5 per cent of the genome known to code for proteins. To speed up the process, a four-year Anglo-French Eureka pre-competitive technology research project, Labimap 2001, aims to develop and market a series of machines to automate time-consuming sequencing operations.

According to research minister Hubert Curien, the estimated FF150 million ( $\$ 29$ million) the state currently spends on genome research each year is "insufficient and too dispersed to support international competition". After consultation with leading French researchers, the Ministry of Research and Technology has decided to set up a new public body with its own scientific advisory cornmittee, to distribute an extra FF50 million next year and FF100 million in 1992. "We do not intend to use this money for construction", says Curien. Instead, the grants will go to some of the 500 researchers and 67 laboratories already engaged on genome research. The main role of the new body is to coordinate the national effort, ensure international liaison and encourage the commercial exploitation of discoveries.

Curien is openly critical of the "messianic" declarations of James Watson, director of the US National Institutes of Health human genome research project. Last year, Watson warned that if the international community did not share the costs of sequencing the human genome, it would be denied access to the data. This challenge is "unparalleled in the medical and biological sciences", says Curien.

France has already played a key part in human genome research, through its centre for the study of human polymorphisms (CEPH), set up by Jean Dausset, a Nobel laureate, and Daniel Cohen in 1984. With a FF40 million annual budget (mostly state-funded but also supplemented with grants from the US National Institutes of Health the Howard Hughes Medical Institute and national charities), $\mathrm{CEPH}$ makes available to researchers throughout the world a unique bank of genetic material from over 60 very large families. The aim is to use standard material more efficiently to localize and sequence the genes responsible for the 4,000 known hereditary illnesses."

Peter Coles

\title{
Equality for the sexes?
}

\section{London}

A MALE hormone-based contraceptive moved one step closer to practical reality last week with the announcement in The Lancet that pregnancies have been successfully prevented in the sexual partners of men receiving weekly injections of the hormone testosterone enanthate.

Earlier studies had already suggested that sperm production stops in a large proportion of men within a few months of their being injected with testosterone. But the new World Health Organization (WHO) study, spanning seven countries, is the first to test the supposition that these men become infertile. One hundred and nineteen men who appeared not to be producing sperm relied on the injections as their only method of contraception for 12 months. Only one of the men's partners became pregnant, suggesting that the male contraceptive is more efficient than female contraceptive pills (and far more efficient than the use of condoms).

The authors of the report indicate that even the single apparent failure may have been the result of an extramarital encounter. A small number of men withdrew from the study, complaining of acne or increased aggressiveness, but there was no sign of the more serious of the anticipated side effects, such as prostate problems, liver enzyme abnormalities and shrinking testicles.

Geoffrey Waites, who coordinated the study from WHO's base in Geneva, says the next step is to run a similar study on men whose sperm production has been much reduced, rather than halted. Six months of hormone injections completely abolished sperm production in only 65 per cent of the men, but laboratory tests suggest that the few sperm cells in the ejaculates of the remainder are "not functional", says Waites.

Finding an alternative to weekly hormone injections will be important if the treatment is to be accepted as a practical method of contraception. A male pill is unlikely, because testosterone is destroyed rapidly in the stomach, but Waites says it should be possible to achieve the same results with only three injections a year. WHO has developed a formulation of testosterone bound to esters which is expected to release the hormone steadily over a number of months, after an injection into muscle.

Pramilla Senanayake, from the International Planned Parenthood Federation, hopes the treatment will be generally available within five years, providing a realistic alternative to the almost universally disliked condom. Many Islamic people are also opposed to surgical techniques, such as vasectomy, Senanayake says, but injections should be more acceptable.

WHO is also developing a reversible vasectomy technique, currently being tested in China. Small silicone plugs are injected into the sperm ducts, and can be removed in a relatively simple operation. But a 'contraceptive vaccine' for men, which attracted considerable media attention when the idea was first mooted, is still many years away. Paul Primakoff, from the University of Connecticut, has shown that male guinea-pigs injected with the sperm surface protein $\mathrm{PH}-20$ are infertile (see Nature 335, 543; 1988). But his group has since found that the treatment sets up an autoimmune inflammatory reaction in the testes, which Primakoff describes as "a clearly unacceptable sideeffect" for a human contraceptive.

Peter Aldhous

\section{NUCLEAR WEAPONS}

\section{US halts plutonium processing}

Boston

THE United States last week quietly abandoned its plans to continue to produce plutonium. Although the US government has often said that it has no shortage of plutonium, the change in policy owes more to concern about safety at plutonium production plants than either the existence of plentiful stocks of plutonium or the warming of East-West relations.

The Department of Energy will not now reopen the the Purex processing plant, which since 1955 has separated plutonium for use in nuclear weapons from the spent fuel of nuclear reactors.

The Purex plant, located at the Hanford Nuclear Reservation in Washington state, was the only remaining US plutonium processing plant and was closed unexpectedly at the end of 1988 for safety reasons. Since then it has been the object of a lawsuit by a coalition of environmental groups. The plant had been scheduled to reopen this spring, but the Department of Energy now says it will leave the plant on "standby" and will prepare an environmental impact statement "to assess the likely effect of any future restart" of the plant.

The US Congress last week also cut funds for a new $\$ 385$-million plutoniumprocessing laboratory at the Los Alamos National Laboratory in New Mexico. The decision followed the cancellation by President Bush last spring of plans to build a plutonium-processing plant in Idaho, and a congressional decision in August to cut money for a plutonium-processing facility at the Department of Energy Rocky Flats installation in Colorado. Seth Shulman 